\title{
Inequality of Opportunity for Higher Education
}

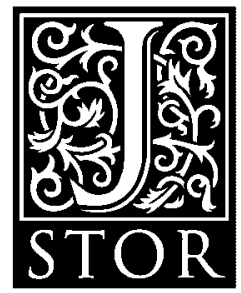

\author{
William H. Sewell \\ American Sociological Review, Volume 36, Issue 5 (Oct., 1971), 793-809.
}

Your use of the JSTOR database indicates your acceptance of JSTOR's Terms and Conditions of Use. A copy of JSTOR's Terms and Conditions of Use is available at http://www.jstor.org/about/terms.html, by contacting JSTOR at jstor-info@umich.edu, or by calling JSTOR at (888)388-3574, (734)998-9101 or (FAX) (734)998-9113. No part of a JSTOR transmission may be copied, downloaded, stored, further transmitted, transferred, distributed, altered, or otherwise used, in any form or by any means, except: (1) one stored electronic and one paper copy of any article solely for your personal, non-commercial use, or (2) with prior written permission of JSTOR and the publisher of the article or other text.

Each copy of any part of a JSTOR transmission must contain the same copyright notice that appears on the screen or printed page of such transmission.

American Sociological Review is published by American Sociological Association. Please contact the publisher for further permissions regarding the use of this work. Publisher contact information may be obtained at http://www.jstor.org/journals/asa.html.

American Sociological Review

(C1971 American Sociological Association

JSTOR and the JSTOR logo are trademarks of JSTOR, and are Registered in the U.S. Patent and Trademark Office. For more information on JSTOR contact jstor-info@umich.edu.

(C2001 JSTOR

http://www.jstor.org/

Thu Aug 16 11:04:23 2001 


\title{
AMERICAN SOCIOLOGICAL REVIEW
}

October 1971

Volume 36 , No. 5

\section{INEQUALITY OF OPPORTUNITY FOR HIGHER EDUCATION *}

\author{
William H. SEWelL \\ University of Wisconsin \\ American Sociological Review 1971, Vol. 36 (October):793-809
}

\section{INTRODUCTION}

$\mathrm{H}$ IGHER education in American society gains only a part of its significance from the personal satisfactions and self-realization that come from general learning and the mastery of high level skills. More importantly, higher education confers increased chances for income, power, and prestige on people who are fortunate enough to obtain it. ${ }^{1}$ In modern technological so-

\footnotetext{
* Presidential Address, 66th Annual Meeting of the American Sociological Association, August 30, 1971, Denver, Colorado. The research reported herein was supported by grants from the National Institutes of Health, U.S. Public Health Service (M-6275) and the Social and Rehabilitation Service, Social Security Administration (CRD-314). I wish especially to thank Robert $M$. Hauser for his critical comments and suggestions and for his corrtribution to the analytical work reported here. David Mechanic and Bryant E. Kearl made valuable suggestions for the revision of an earlier draft of this paper. I wish also to acknowledge the contributions of my professional associates on this project over the years: Archibald O. Haller, Kenneth G. Lutterman, Vimal P. Shah, Janet A. Fisher, Ronald M. Pavalko, Robert M. Hauser, J. Michael Armer, Alan M. Orenstein, Eldon L. Wegner, Alejandro Portes, George W. Ohlendorf, Herschel Shosteck, Victor Jesudason, Dorothy M. Ellegaard, and Ruth M. Gasson.
}

1 There is a vast literature on the economic benefits of education which shows that those with advanced education enjoy much higher annual and lifetime earnings than those with lesser education. See especially Schultz (1963), Morgan and David (1963), Becker (1964), Innes et al. (1965), Weisbrod and Karpoff (1958), and Bowman (1971). Our own unpublished results indicate that, even when we control for ability, average annual earnings of college graduates are considerably higher than the earnings of those who obtained less posthigh school education. These results are based on 1967 data, and these earning differentials doubtless will increase over the years as those in the pro- cieties the allocation of social position is increasingly dependent on higher education. Entrance into an ever enlarging range of valued occupations is restricted to those whose educational attainments beyond secondary school are presumed to have given them the habits of thought, attitudes, and special skills that these occupations require (Sorokin, 1927:169-172, 187-193; Lenski, 1966:389-395; Blau and Duncan, 1967: 401-441; Miller and Roby, 1970:119-141; Hauser, 1970).

It has long been accepted that training for the higher professions should be an almost exclusive monopoly of colleges and universities. More recently this near monopoly has been extended to include many subprofessional and technical occupations as well. Even the training required for the skilled blue-collar and lower level whitecollar occupations-which formerly was acquired on the job, through apprenticeships, or in vocational curricula in high schoolshas increasingly been shifted to post-secondary institutions.

Recently there has been a good deal of criticism of the overemphasis on credentialism and the certification role that colleges and other educational institutions perform (Miller and Reissman, 1969; Berg, 1970; Newman et al., 1971:38-43). This criticism is particularly persuasive whenever it can be shown that the educational requirements for entry into an occupation have little bearing on the activities of that occupation. It is especially unfortunate that when such requirements are artificially high, many otherwise qualified persons from disadvantaged

fessions and business enter the more productive phases of their careers. 
backgrounds are excluded from desirable occupations. However, with high school graduation becoming almost universal in the United States and with the level of technology increasing, it seems quite likely that the trend will be toward more, not less, dependence on post-secondary institutions to select, train, and certify people for an enlarging variety of occupations.' Those who fail to obtain this training, for whatever reasons, will be severely disadvantaged in the competition for jobs and in many other areas of social life as well.

With occupational selection, training, and certification carried out mainly through the schools, and particularly in post-secondary institutions, life chances will not be equal until opportunities for advanced education are equal. The extent to which opportunities for higher education are contingent on characteristics of social origin that are not relevant to learning-most notably sex, socioeconomic origins, race and ethnic background -is a matter of great importance to the study of social stratification and a pressing problem to a society that stresses equality of opportunity as a national goal. ${ }^{3}$

The purpose of this paper is to review the research my associates and $I$ have been

\footnotetext{
${ }^{2}$ We find it difficult to come up with a better alternative to heavy reliance on the educational system for the training and certification function. We agree that other ways to qualify for jobs must remain open and should be expanded, but we would question seriously the equity and efficiency of relying heavily on the selection and training procedures of the many thousands of employers in the job market. Incidentally, some of the criticism of credentiahism, insofar as it deals with racial minorities, seems to be misplaced because our best evidence indicates that a large fraction of the disadvantage of these minorities in occupation and income accrues to those who have obtained the right educational credentials but are still discriminated against in the job market (Duncan, 1968).

${ }^{3}$ Recent concern with inequality of opportunity in higher education has resulted in a number of reports and recommendations for national policy. Among the most prominent of these are the Reports of the Carnegie Commission on Higher Education (see especially 1968, 1970a, 1970b) and the Report of the U.S. Department of Health, Education, and Welfare (1969): Other references are given in later footnotes. For a provocative discussion of the evolution of the concept inequality of educational opportunity, see Coleman (1968). For an cutstanding statement on inequality and opportunity, see Duncan (1969).
}

doing on this subject, ${ }^{4}$ and to suggest some of its implications for public policy. First, I will summarize briefly our findings, then discuss some of the results of our efforts to elucidate the complex relationships between socioeconomic background and educational attainment, and finally $\mathrm{I}$ will consider their policy implications.

Our research has been based on a longitudinal study of approximately 9,000 randomly selected Wisconsin high school students who have been successfully followed since they were high school seniors in 1957.5 Our data provide information not only on socioeconomic origins, sex, academic ability, and post-high school educational and occupational attainments, but also on such matters as the student's performance in high school, the expectations of parents and teachers and peers, and the student's educational and occupational aspirations. With these data we have examined in detail inequalities in opportunities for higher education and have also devised explanatory models for the educational attainment process.

\section{Inequalities in Higher Education}

Using such measures of socioeconomic status as parental income, father's and mother's educational attainment, and father's occupation-either singly or in combination--we have found enormous differences in educational opportunities among

4. The most directly pertinent publications from our research are: Sewell (1964); Sewell and Haller (1965); Sewell and Armer (1966a and 1966b); Sewell and Shah (1967, 1968a and 1968b); Sewell et al. (1969); Wegner and Sewell (1970); and Sewell et al. (1970).

5 The original 1957 sample consisted of 10,321 students who were followed up in 1964 by means of mailed questionnaires and telephone interviews. Follow-up data were obtained for 9,007 or $87.2 \%$ of those in the original sample. Since that time additional information on the earnings of the students has been obtained periodically, but these data are used only incidentally in this paper. Extensive comparisons of the characteristics of the original and follow-up sample show little if any bias in the follow-up sample. For a description of the original survey, see Little (1958:1-6). A brief description of the follow-up survey is given in Sewell and Shah (1967:6-8). Much more complete information on the data and procedures used in the analysis reported in this paper will be available in a book currently in preparation (Sewell et al., forthcoming). 
the various socioeconomic groups and between the sexes. These differences are great regardless of what socioeconomic indices are used and regardless of how restrictively or broadly opportunity for higher education is defined--whether it is taken to mean college entry, college graduation, professional or graduate study, or simply continuation in any kind of formal education beyond high school. ${ }^{6}$

To illustrate. When we divide our cohort into quarters ranging from low to high on an index based on a weighted combination of our indicators of socioeconomic status, we estimate that a high SES student has almost a 2.5 times as much chance as a low SES student of continuing in some kind of post-high school education. He has an almost 4 to 1 advantage in access to college, a 6 to 1 advantage in college graduation, and a 9 to 1 advantage in graduate or professional education. In the middle SES categories the rates are consistently between these extremes: the lower the SES group, the more limited the opportunities at each higher level of education.

These socioeconomic differentials in educational attainment hold for both sexes. However, the educational chances of males are uniformly greater than those of females at every SES level. For example, in the bottom SES category males have a $26 \%$ advantage over females in obtaining any further schooling, a 58\% advantage in attending college, an $86 \%$ advantage in completing college, and a $250 \%$ advantage in attending graduate or professional school. Likewise, in the top SES category males have an $8 \%$ advantage over females in obtaining any further schooling, a $20 \%$ advantage in attending college, a $28 \%$ advantage in completing college, and a $129 \%$ better chance of attending graduate or professional school. Thus, the advantage of males is greatest in the lower SES categories and least in the top SES category.

Even when we control for academic ability by dividing our sample into fourths according to the students' scores on standardized

${ }^{6}$ The detailed tables on which the conclusions in this section of the paper are based are given in Sewell et al. (unpublished). They have also been presented in somewhat different form in Sewell and Shah (1967:9-16). tests, ${ }^{7}$ we find that higher SES students have substantially greater post-high school educational attainment than lower SES students. For example, among students in the lowest fourth of the ability distribution, those in the highest SES category have a 2.5 times advantage over those in the lowest SES category in their chances to go on to some form of post-high school education. For students in the highest ability fourth, the chances of continuing their schooling are 1.5 times greater if they are from the highest rather than the lowest SES category. Similarly, in the lowest ability fourth the rate of college attendance is 4 times greater for the highest SES group than for the lowest SES group. Among the top quarter of students in ability, a student from the lowest SES category is only about half as likely to attend college as a student from the highest SES category. A similar pattern holds for the chances of graduating from college, where corresponding ratios range from 9 to 1 among low ability students to 2 to 1 among high ability students. At the level of graduate or professional school entry, where we would expect ability considerations to be determinant, the odds are 3.5 to 1 in favor of high SES over

\footnotetext{
${ }^{7}$ Academic ability -its definition, its dimensions, its causes, and its measurement-presents vexing questions to social scientists. There is a long history of debate on these issues which has not led to univeral agreement on any of them (Goslin, 1963: 123-151; Bloom, 1964:52-94; Jensen, 1969). We take the position that by the end of high school the widely used tests of academic ability yield essentially valid measures of individual potential for success in the system of higher education (Lavia, 1965:42-63; Eckland, 1967). In this study we have used a single standardized measure of academic ability, the Henmon-Nelson Test of Mental Maturity, obtained in the junior year of high school (Henmon-Nelson, 1954). This test, like similar tests, has been said to be culture-bound and, therefore, unfair to lower class respondents (Eells et al., 1950; Lefever, 1959). Whatever the merits of that argument, any class bias in the test will lead us to underestimate the independent influence of socioeconomic background on educational attainments. Since our interest lies in demonstrating that socioeconomic background has an effect independent of academic ability on the completion of every stage of posthigh school education, the test bias, if any, will have a conservative effect on our conclusions. If significant social class differences in educational attainment are still in evidence when measured ability is controlled, there will be no doubt abou't the existence of unequal opportunities in higher education.
} 
low SES students, even in the high ability category.

The patterns we have described hold for both women and men. When SES and ability are both controlled, women have lower probabilities of obtaining any further schooling, of attending college, of graduating from college, and of entering graduate or professional school. The differences in rates of attainment between the sexes tend to be lower at the higher levels of attainment and in the higher SES groups, but are still marked at all educational levels and in all SES categories.

Our findings lead inexorably to the conclusion that in their opportunities for higher education the members of this sample cohort seldom escape the influence of their social origins. The selective influences of socioeconomic background and sex operate independently of academic ability at every stage in the process of educational attainment. Social selection is most vividly apparent in the transition from high school to college, but it is operative at every other transition point as well. Those who overcome the handicap of origin status or of sex at one level of the system find themselves again disadvantaged in moving on to the next level.

The results presented thus far do not fully indicate the numerical magnitude of the educational inequalities suffered by women and low socioeconomic status members of this cohort, consisting of approximately 36,000 persons. For this purpose we present an estimate obtained by assuming that the members of each SES and ability category, regardless of sex, should have had the same educational opportunities as high SES males of equal ability. Had this goal been realized, there would have been an increase of 8,800 or $32 \%$ more students continuing their schooling beyond high school graduation; 10,089 or $43 \%$ more students entering college; and 5,770 or $47 \%$ more students graduating from college.

Socioeconomic origin contributes more than sex to the failure of all students to enjoy the same educational opportunities, but even so the result of equalizing women's opportunities would have been to increase by 1,176 or $28 \%$ the number of women who would have obtained some further schooling beyond high school; by 2,157 or $52 \%$ the number who would have attended college; and by 1,455 or $68 \%$ the number who would have graduated from college.

Despite Wisconsin's proud record of providing public and private scholarships and low tuition rates in its diverse system of public higher education, by any standard these figures represent a massive failure to provide equality of opoprtunity for higher education to qualified students of all SES levels and both sexes. The results are that the state and the nation suffer a great loss in potential, high level manpower and the young people involved pay through reduced life chances.

Our study reveals still other inequities suffered by students from low SES groups in their quest for higher education. Holding academic ability constant, low SES persons are less likely to go to college immediately after high school graduation, much less likely to attend or to be graduated from high quality colleges, more likely to drop out of college if they enter, less likely to return if they drop out, and more likely to have their college careers interrupted by military service. On all of these dimensions except military service, women fare worse than men.

It is indeed regrettable that generally comparable and adequate data on inequality of opportunity for higher education are not available for large and representative samples for the nation as a whole. ${ }^{8}$ The data

8 Among the national studies in which some attempt has been made to follow up high school students are: the Educational Testing Service (1957) study of college plans and enrollment; Project Talent (Flanagan et al., 1962a, 1962b; Flanagan et al., 1964, 1966; Shaycoft et al., 1963; Shaycoft, 1967); the Trent and Medsker (1968) study of 10,000 high school graduates; the Nam and Cowhig (1962) study of factors related to college attendance of high school graduates; the Bureau of the Census and Bureau of Applied Social Research study of factors related to high school graduation and college attendance (U.S. Bureau of Census, 1969); and study of educational and occupational experiences of male youth by Parnes et al. (1970) and Zeller et al. (1970). Another national sludy--The Institute for Social Research study of adolescent boyswhich will have follow-up data eventually, is "Youth in Transition," by Bachman et al. (1969). Unfortunately, there is little uniformity in the sampling, variables, follow-up procedures, or data analysis in these studies, thus making impossible anything but gross comparison of results. Also it is unfortunate that the design of the Equality of Educational Opportunity Study (Coleman et al., 1966) will not permit any follow-up of the over 600,000 students included in that national survey. 
that exist on national samples, particularly the badly flawed data from Project Talent, 9 remarkably parallel the trends in our data whenever similar analysis has been undertaken (Folger et al., 1970:305-324). We have no basis for making estimates of national parameters, but to the extent that our data are representative they furnish solid documentation for the claim that there is substantially reduced opportunity for higher education in America for those of lower socioeconomic origins and for women, and that this inequality cannot be explained by differences in academic ability. Despite the spectacular increase in the numbers attending college during the past decade, there is no good reason to believe that socioeconomic differentials in opportunity for higher education have altered appreciably. ${ }^{10}$

${ }^{9}$ The most glaring defects of the Project Talent Study were its very low response rate $(32 \%)$ in the five-year follow-up study and high rates of nonresponse to items on the questionnaire. A small nonrandom subsample of nonrespondents to the mailed questionnaire was interviewed, and weighting procedures based on this subsample were employed to make estimates for the larger sample and eventually for the populaton studied (Folger et al., 1970:Appendix B). We believe that this technique was not adequate to compensate for bias due to nonresponse, e.g., computations we have made using Project Talent data for the 1965 panel (Folger et al., 1970:Appendix B, Table B2) indicate that $36 \%$ of the males in their sample graduated from college, wlrereas the census of 1970 data shows that only $26 \%$ of U.S. males in the age cohort 25-29 (the age cohort most comparable with their sample) had completed four or more years of college (U.S. Bureau of Census, 1970).

${ }^{10}$ The booming college enrollments of the Sixties have led many to believe that opportunities for higher education must have become much more widespread during the decade. This is in part true but, from computations we have made using information on the college experiences of persons 20-24 years old in 1960 and 1970 (U.S. Bureau of Census, 1960, 1970), we found that $34 \%$ of the increased college experience in the decade was due to the growth in the size of the age cohort, $30 \%$ due to the increased rate of high school graduation, and $36 \%$ due to increase in the rate of college entry. Unfortunately, we know of no evidence that would permit us to draw a firm conclusion as to whether the increased rate of college enrollment has resulted in a higher rate of college going among high school graduates from the lower SES groups. One calculation we have made, using data from a U.S. sample, indicates that the proportion of students of manual and service origins enrolled in college increased by $7 \%$ during the decade, while the pro-
It is also unfortunate that no comparable data or analyses exist for blacks, Chicanos, Puerto Ricans, or American Indians. These groups are overrepresented in the lower socioeconomic levels of our society, and they suffer disadvantages due to racial and ethnic discrimination over and above those that characterize the poor in the overwhelmingly white population of Wisconsin (Duncan and Duncan, 1968; Duncan, 1968). We do know that in 1970 only $65 \%$ of blacks aged $20-24$ had graduated from high school, in contrast to $83 \%$ of whites. Only $23 \%$ of blacks in the same age cohort had ever completed a year of college, in contrast to $39 \%$ of the whites. In the cohort aged $25-29$, only $7 \%$ of all blacks had college degrees, in contrast to $17 \%$ of whites. And only slightly over $1 \%$ of the blacks in this same age cohort had completed as much as one year of professional or graduate education, compared with $6 \%$ of the whites. ${ }^{11}$ The current enrollment situation at the undergraduate and the graduate and professional levels is still heavily unbalanced. In 1970 only $7 \%$ of the students enrolled in colleges and universities in the United States were black, and blacks made up only $2 \%$ of current graduate school enrollments and less than $2.5 \%$ of the enrollments in medical schools, although blacks were approximately $12 \%$ of the affected age cohorts (Wright, 1970). The situation of Puerto Rican, Mexican, and Indian Americans is less well known, but may be as bad. We believe that if data comparable with those for our study were available on black and other disadvantaged minorities, the relationships would be even more marked.

portion of white-collar students increased by less than $2 \%$ (U.S. Bureau of Census, 1961, Current Population Reports, P-20, No. 110, Table 5, and 1971, P-20, No. 222, Table 7). This is a notable increase, but is not likely to have had any marked effect on the validity of the general pattern of socioeconomic differentials in educational opportunity revealed by the Wisconsin data. The fact that the pattern we have described has been quite stable over the years is indicated by Spady's analysis of the data from the 1962 current population supplement, "Occupational Changes in a Generation," showing that SES differences in college attendance had increased over the decades covered in that study (Spady, 1967).

11 These figures are based on computations from data included in Current Population Reports (U.S. Bureau of the Census, 1970 and 1971). 


\section{The Educational Attainment Process}

In addition to the descriptive analysis reported thus far, we have attempted to understand more fully the process of higher educational attainment. We have identified a number of experiences that young people undergo in their formative years which have an important bearing on post-high school educational outcomes. These include level of performance in high school, whether significant others encourage or discourage aspirations for higher education, and whether one actually develops high educational and occupational aspirations. All of these experiences intervene between the social origins, academic ability, and sex characteristics of the individual and become the mechanism through which these background characteristics transmit their influence. In addition, these same experiences have direct and indirect effects of their own, quite independent of the background characteristics.

This complex multivariate process has been the focus of much of our recent research, and we have been developing and testing linear causal models to further explicate the process of attainment. Building on the work of Blau and Duncan (1967:163205), we have devised and published a linear recursive model that attempts to elaborate and explain the effects of socioeconomic origins and academic ability on educational achievements and occupational attainments as these influences are mediated by social psychological processes (Sewell et al., 1969; Sewell et al., 1970).

Recently we have further elaborated our model by disaggregating socioeconomic status into its component parts-parents' income, mother's education, father's education, and father's occupation-and by decomposition of "significant others' influence" into parental encouragement, teachers' encouragement, and peers' plans. ${ }^{12}$ This enables us to obtain estimates of the individual role of

\footnotetext{
12 The operational definitions of the variables used in the models discussed in this section of the paper are basically the same as given in Sewell et al. (1970:1017) except that educational attainment for parents and students has been recoded into approximate years of schooling rather than the four broad categories used in that report. For further details, see Sewell et al. (unpublished).
}

each of these variables in the educational attainment process. ${ }^{13}$

Because this analysis is quite complicated, we shall present only the major findings for the total sample, making references to sex differences where they are especially large or interesting.

We begin the analysis with a very simple model that includes only the four socioeconomic background variables. We find that these four socioeconomic background variables taken together account for $18 \%$ of the total variance in years of post-high school educational attainment. Whether we look at linear or nonlinear effects, each of the four has an approximately equal, direct influence on educational attainment and on all other intervening variables in the model. This approximate equality of effects of such stratification variables as parental education, occupation, or income suggests that there may be little merit in the efforts of some social scientists to interpret all social inequalities in terms of any particular stratification variable.

What is impressive is not so much the extent to which socioeconomic status governs the life chances of any particular individual, but rather the extent to which it reduces the aggregate or average educational achievements of those from the lower strata. For example, each year of parental education, father's or mother's, was worth one-tenth of a year of higher education for their childafter the effects of father's occupational status and family income were taken into account. Thus, the children of parents with only grade school education obtained on the average one and one-half years less education than the children of parents who were both college graduates-even if their fathers had similar jobs and their families had similar incomes.

Likewise, a thousand dollar increase in the annual income of a family on the average yielded an increase of .08 of a year in the educational attainment of their childslightly less than an additional year of education of either parent. Thus, a shift in in-

\footnotetext{
13 The tables and formulae for the computations summarized in this section would require several printed pages to reproduce. Consequently they are not presented here but will be given in full in Sewell et al. (unpublished).
} 
come from the poverty level of $\$ 3,000$ below which $18 \%$ of those in the Wisconsin sample fell-to the median income at that time, $\$ 6,000$, increased the average years of schooling by a quarter of a year when the effects of parental education and occupation were taken into account. A shift from the poverty line to $\$ 10,000$-which was exceeded by only $11 \%$ of the families in the Wisconsin sample-led to an increase of more than half an additional year of post-secondary schooling.

When we add academic ability to the model, the explained variance in higher educational attainment is increased from 18 to $30 \%$. The additional $12 \%$ represents a large component of the variance in educational attainment that is completely independent of socioeconomic origins. An important component, varying between 20 and $30 \%$, of the effects of each of the socioeconomic status variables is mediated by academic ability. At the same time the influence of ability on attainment is clearly not spurious. Only onefifth of the association of academic ability with educational attainment may be attributed to its association with socioeconomic background. Whether one thinks of measured ability as a valid psychological trait or as an administratively convenient basis for social selection, it seems apparent that the effects of ability on schooling are not merely a reflection of one's SES background. We think this is particularly germane to current discussions of the social role of testing. ${ }^{14}$

Next, in order to explain more completely the ways in which socioeconomic status origins influence post-high school attainment, we further complicate the model by adding

\footnotetext{
14 Critics of the use of tests for selection for higher education have often overlooked the fact that many poor children of all races score well on the tests and (through family sacrifices and their own efforts and often) with the help of studentaid programs are freed from the handicaps of their social origins. We would not wish to see any reorganization of testing in our society that would overlook this valuable function in efforts to eliminate any undesirable side effects of testing. An interesting result of recent criticisms of testing has been a broadened conception of the responsibility of the major testing services to seek other valid methods of discovering the potential of disadvantaged students and to help disadvantaged students find appropriate educational institutions in which to develop their talents.
}

three sets of social psychological intervening variables: (1) high school performance, (2) significant others' influence, and (3) educational and occupational aspirations. We believe that these variables intervene in the order indicated to mediate the effects of socioeconomic status and academic ability on higher educational attainment. Taken as a whole, these intervening variables account for a large part of the effects of each socioeconomic status variable on post-high school educational attainment. Some 85 to $90 \%$ of the total association of each socioeconomic status variable with attainment is mediated by the variables in the model, of which about $75 \%$ is mediated by the social psychological variables, leaving only 10 to $15 \%$ to be explained by other variables not in the model, by measurement error, and by socioeconomic discrimination. Still, even with this powerful model which explains over $55 \%$ of the variance in higher educational attainment, socioeconomic origins continue to influence directly one's chances for educational attainment.

The extent to which our model explains the effects of socioeconomic origin on ultimate educational attainment is remarkable in light of the fact that none of our intervening variables pertains to the post-secondary experience of the cohort. Even for young persons who succeed in graduating from high school, the effect of social background on later educational achievement is largely explicable in terms of events which took place during the high school years.

Again, with this more complex model it is noteworthy that the interpretations for total associations are very similar for each of the SES variables. About $12 \%$ of the influence of each SES variable on higher educational attainment is direct. About $16 \%$ is due to the association with the other SES variables, about $11 \%$ is ultimately mediated by academic ability and high school performance, about $23 \%$ is eventually mediated by significant others' influence, and about $38 \%$ is ultimately mediated by educational and occupational aspirations.

Not only does the model interpret the various ways in which SES variables influence higher educational attainment, but also it interprets the effects of academic ability. Of the total association between academic 
ability and educational attainment, $18 \%$ is due to the unmediated effect of ability, $21 \%$ is due to the relationship between academic ability and socioeconomic background, and the remaining $61 \%$ is mediated by the social psychological variables in our model. This indicates that the influence of academic ability can only in a minor way be attributed to SES considerations, but rests more solidly on its direct and pertinent influence on academic performance, and its direct and indirect influences on significant others and on educational and occupational aspirations. In this context it is also pertinent that the model indicates that SES has no effect on performance in high school independent of academic ability.

Next, in the analysis of our full model, we introduce the effects of parental encouragement, teachers' encouragement, and the educational plans of friends. In looking at the effects of these significant others on educational attainment, we are struck by the evidence that parental encouragement and friends' plans depend heavily on the student's socioeconomic origin. Teachers' encouragement, on the other hand, depends much more heavily on ability and academic performance. Indeed, teachers are not perceived to engage in direct socioeconomic status discrimination as parents and peers apparently do, but rather depend mainly on judgments of student academic ability, particularly as it is validated by school performance.

We find that the influence of parents on educational and occupational aspirations and ultimately on attainment of higher education is about twice that of teachers, and the influence of friends only slightly less than that of parents. Holding constant all of the other factors we have included in the model up to this point (SES, academic ability, school performance, parental encouragement, and friends' plans), we find that teachers' encouragement is worth an additional 0.3 of a year of schooling-whereas the net values of parental encouragement and friends' plans are 0.9 of a year and 0.7 of a year, respectively. While all three variables have important effects on students' educational attainments, we are led to conclude that teachers' expectations of students are not a powerful mediating factor in the process of educa- tional stratification. But far from reflecting overt or covert status discrimination, on the whole teachers' expectations seem to be based on academic ability and performance, and as such they make a fundamental though modest contribution to the equalization of opportunities.

Although our model is quite successful in accounting for socioeconomic differentials in educational attainment, it is less successful in accounting for sex differences-which favor men by approximately one-half year of educational attainment on the average. Our analysis indicates that women are most seriously disadvantaged relative to men in levels of teachers' and parents' encouragement and in their own levels of educational aspirations. They enjoy some advantage over men in that they get higher grades in high school and have slightly higher perceptions of their friends' plans and somewhat higher occupational aspirations. Our model tends to predict higher average educational attainments for women than they actually achieve. This may be due to its failure to represent crucial aspects of women's high school experiences, or it may be that the primary sources of the lower attainments of women must be sought in the months and years immediately following the completion of high school. We are inclined toward the latter view, for the effects of socialization in the family and in the school are already manifest in women's levels of school performance, of significant others' influence, and of aspiration.

\section{Policy Implications}

What bearings do our findings have for policies designed to recluce inequality in higher education? Certainly, in this large cohort there is striking evidence of its pervasiveness. Although socioeconomic origin plays an inportant part in inequality in higher education, our analysis indicates that its role is far from simple and direct. Its effects tend to be mediated largely by social psychological factors, which in turn also have independent influences on the processes of educational attainment. Moreover, when we look at the components of socioeconomic status-father's and mother's education, father's occupation, and family income-we 
find that no one of them plays any unique part in the causal system explaining attainment in higher education. This is unfortunate from the standpoint of policy considerations. One would have wished that family income might have had a larger and a more special set of effects because it is the aspect of socioeconomic background most readily amenable to change. ${ }^{15}$ But our evidence raises doubt that programs based on family income supplementation alone will result in any rapid and marked reduction in inequality in higher education. This is not to deny the importance of income in obtaining access to higher education, but it is to warn that family income programs, however desirable they may be for reducing other social inequalities, will not bring quick or dramatic results in overcoming inequality in higher education. ${ }^{16}$ Certainly we should not rely on this means alone to bring about equalization of opportunity for higher education.

Rather, I would argue for a more targeted economic approach. ${ }^{17} \mathrm{I}$ believe that programs specifically limited to financing postsecondary educational costs based strictly on student need would be the most effective and equitable approach to the problem. Besides making it possible for needy students to

15 For a provocative discussion of the use of policy variables, see Cain and Watts (1970) and replies by Coleman (1970) and Aigner (1970).

16 Rainwater (1970:398-425) has presented a strong case for a national policy of income redistribution as the most effective way of reducing social inequality. In this connection he argues that it is unlikely that educational outcomes for poor children can be greatly improved without increasing the incomes of their families. Masters (1969) presents evidence that although the short-run effects of income transfer programs on educational retardation and dropout may be small, the longrun effects may be quite important.

17 Financial programs have been stressed by many economists. For a comprehensive review of the various plans, see the papers by Roger E. Bolton, W. Lee Hansen and Burton A. Weisbrod, Alice Rivlin and Jeffrey $\mathrm{H}$. Weiss, Andre Daniere, Clark Kerr, Howard R. Bowen, Jerrold R. Zacharias, and Roger Freeman in a report on financing higher education submitted to the Joint Economic Committee of the Congress of the United States (1969). See also the papers by Theodore W. Schultz, Mary Jean Bowman, W. Lee Hansen and Burton A. Weisbrod, Howard R. Bowen, Robert W. Hartman, Roger A. Freeman, Robert L. Farrell and Charles J. Andersen, John P. Mallan, and M. E. Orwig in Orwig (1971a). continue their education, such a grants program might have desirable indirect effects on the educational aspirations and achievements of the disadvantaged. For example, if students and parents became aware that it was national policy to make grants to cover the full cost of post-secondary schooling for qualified students whose families had incomes too low to bear these costs themselves, it is entirely conceivable that this knowledge would lead to better performance in school because now performance would have a greater likelihood of being rewarded. Parents and teachers might then give more attention to the student's academic growth, with consequent favorable effects on the development of the student's self-conceptions, ambitions, and aspirations. All of this might lead to a greater likelihood that the student would continue education beyond high school and be more successful in post-high school studies.

I advocate that all new subsidy programs be limited to those who need the subsidy. There is mounting evidence that existing subsidy programs for higher education do not go primarily to needy students. Not only do federal moneys for training and research go mainly to institutions that are attended primarily by middle- and high-income students, but also most other forms of institutional aid go to high prestige colleges and universities. Even student-aid moneys are not primarily concentrated in the community colleges, city colleges, and less prestigious colleges that serve the poor (Rivlin, 1970:9). Moreover, in their recent analysis of the distribution of subsidy for public higher education in California, Hansen and Weisbrod $(1969 \mathrm{a} ; 1969 \mathrm{~b})$ argue that because higher income students are more likely to go to college, to attend the most expensive public institutions, and to stay in college longer, their families are in effect receiving a much greater educational subsidy from the state than are low income families. ${ }^{18}$ Probably the same trend would be revealed and possibly accentuated in states with less avail-

\footnotetext{
18 Hansen and Weisbrod's analysis (1969a, 1969c) has drawn critical substantive and methodological comment from Pechman (1970), which in turn has been answered by Hartman (1970). Pechman (1971) has recently made further comments and has been replied to by Hansen and Weisbrod (1971a).
} 
ability of public higher education. Consequently, new programs for the subsidy of higher educational opportunity should be limited to students who need the subsidy in order to continue their education beyond high school.

Most of the funds should go directly to students rather than to institutions. ${ }^{19}$ Nor should subsidy programs be limited to those who go to four-year colleges, but rather should include also those whose interests and aptitudes lead them to select community colleges and vocational training schools. Neither would I argue that funds should go only to students of proven academic ability and achievement. Motivated students with qualities that make them admissible to various types of institutions should be given equal opportunity to pursue their education in other appropriate ways. For this group there must be institutions located in all larger communities with open admission policies, programs to remedy prior academic deficiencies, flexible scheduling, pacing and credit loads, and special tutoring and counseling programs (Willingham, 1970:217223; Gordon, 1971). The grants given should be sufficient to enable the student to attend any post-secondary institution-public or private- to which he could gain admission. In the case of the poor, the grants should cover full costs-tuition, books, board, lodging, travel, and even a modest amount for incidental personal expensesand should be in effect as long as the student makes satisfactory progress in school.

The low propensity of the families in our sample to trade family income for education leads me to believe that other funding schemes such as the education opportunity bank, various other loan schemes, and tax credit plans are likely to be much less effec-

\footnotetext{
${ }^{19} \mathrm{We}$ would agree with the Kerr and Rivlin reports that there should be a cost-of-education allowance to help institutions meet the costs of special services that federally aided students might require and for new facilities necessary to accommodate the additional students (Carnegie Commission on Higher Education, 1968; U.S. Department of Health, Education, and Welfare, 1969). For a full discussion of the debate now going on between those who advocate fuller funding of existing institutional programs and those favoring direct payments to students, see Mallan (1971) and Orwig (1971b:331-360).
}

tive in encouraging low-income students to continue their education. Their families are already burdened with debt, and they fear long-time loans-even at low interest or no interest rates-that are likely to run into thousands of dollars before the student has completed his education. Tax credit schemes are likely to appeal greatly to the middle classes who pay heavy income taxes, but not to the poor. In fact, if our goal is to equalize opportunity for post-high school education, it may be necessary, in order to release funds for direct help to students from lower income groups, to reduce current subsidies to students whose parents can afford to pay for their education.

This should not be interpreted as an endorsement for schemes that call for the support of public higher education on the basis of full-cost tuition fees so that all public subsidies for higher education would go only to those who can demonstrate need. ${ }^{20} \mathrm{I}$ believe that tuitions should be kept as low as possible to encourage all motivated students - especially women - to continue their education beyond high school. But even if there were no tuition fees charged for higher education, access to it would, I think, still be painfully inequitable. Consequently, new resources need to be directed at special and extraordinary steps to attract and serve those groups now least well represented in our colleges and universities. ${ }^{21} \mathrm{I}$ believe that a grants program along the lines outlined is administratively feasible and could be put into operation rapidly so that its effects would be apparent in the immediate future.

For those not now in the educational pipeline there must be increased opportunities for recurrent education, including part-time study, work-study programs, education on the job, and various other types of continuing education of both general and technical character (Organization for Economic Cooperation and Development, 1971; Newman, 1971; Carnegie Commission on Higher Education, 1971). These will also require special financing and will be expensive, but our evidence suggests that there are millions of

\footnotetext{
20 Hansen and Weisbrod (1971b) have proposed such a plan for Wisconsin.

21 The basic political issues in federal funding of the various aid-to-higher-education proposals are well covered in Mallan (1971).
} 
disadvantaged youth and adults now in the labor force who dropped out of the educational process early and who have the capacity to profit from such programs. Both as a matter of equity and of intelligent manpower policy, they should be given the opportunity to continue their education.

I do not believe that economic programs alone will be sufficient to overcome inequality in opportunities for higher education. Our analysis also indicates that we must give a good deal of attention to such social psychological factors as the development of cognitive skills, academic performance, the influence of significant others, and the stimulation of educational and occupational aspirations. All of these variables have direct and indirect influences on educational achievement that are quite independent of socioeconomic background. Consequently, any strategies that can be suggested for increasing their strength should be investigated, developed, and given intensive trials in the hope that ways can be found to overcome the deficits in these areas from which so many disadvantaged children suffer.

Particular attention must be given to programs designed to increase the academic ability and performance of lower SES children. Evidence from the Coleman report and other research suggests that many children from disadvantaged homes enter school with a deficit in learning skills that tends to increase steadily throughout the school years, with the consequence that by twelfth grade many lower class children are well behind higher status children in academic skills and achievement (Coleman et al., 1966:20-21). The fact that these academic deficits seem to increase over the years of schooling suggests that special programs designed to develop cognitive and affective skills, beginning in the preschool period and continuing throughout the grades, will be necessary to enlarge the personal and academic potential of socioeconomically disadvantaged children so that they can compete successfully with higher status children.

Unfortunately, current large-scale attempts to improve the cognitive development of socially disadvantaged children have not thus far had promising results (Gordon and Wilkerson, 1966:156-189; Williams and Evans, 1969), despite a good deal of evi- dence from more restricted laboratory and field studies indicating the possibility of rather large and lasting gains. ${ }^{22}$ However, the stakes are so great that rather than give up this line of attack a great deal more ingenuity and effort must be devoted to devising more effective programs, including interventions which involve the family and peers, as well as the school. This will require much research, experimental programming, and structural changes in schools. All of this will be expensive and it may take much more time than we once optimistically thought, but our research suggests that the potential payoffs are very significant, are likely to be largely above and beyond those resulting from economic programs, and are essential if we do not want the early handicaps of disadvantaged children to prevent them from realizing their potential for later academic achievement (Carnegie Commission on Higher Education, 1970a).

Our analysis suggests, also, that programs designed to influence the significant others of disadvantaged students would have important effects on the student's educational aspirations and achievements. One immediately thinks of the possible role that teachers and counsellors might play in programs of this kind. If socioeconomically disadvantaged students with good academic potential were discovered early and high school teachers and counsellors were alerted to the students' potential for development so that they might provide special guidance and encouragement, modest gains might accrue in the students' educational aspiration and attainment levels. On the basis of our data, we would not expect gains of great magnitude because our model does not show teachers' influence to be a very powerful determinant of educational attainment. Still other ways should be sought to involve teachers more actively in the academic and career plans of disadvantaged students. This is important because teachers, unlike parents and peers, are relatively free from socioeconomic bias in stimulating and encouraging promising students.

At the same time there must be pro-

\footnotetext{
22 For comprehensive reviews of research and theory in this area, see especially Deutsch and Associates (1967) and Hess and Bear (1968).
} 
grams to acquaint parents with the academic potential of their child, to get them interested in his educational development, to make them aware of the importance of academic achievement to later educational and occupational opportunities, and to make sure that they know about scholarship and grants programs that would enable their child to continue in post-high school education. I am not optimistic that such programs could effectively provide the encouragement for educational aspirations and achievements that higher status families give their children in the normal course of their socialization. But, again, our research shows that parental influences are so crucial that every effort must be made to utilize this avenue to reduce educational inequalities.

I have no innovative ideas about how peers could be used to stimulate the educational aspirations and achievements of lower status children, but I do believe that their peer culture might be shifted toward educational achievement through programs designed to make school a more interesting and challenging place-by emphasizing competent and sensitive teaching, by restructuring the school around students' interests, by changing the authority patterns in the schools, by elimination of socioeconomic and racial segregation, and by similar innovations. More direct interventions are also possible. Coleman (1965:72-87) has emphasized the use of adolescent peer structures to stimulate intellectual values and performance through intergroup competition. Others have stressed monetary rewards to motivate academic achievement (Effrat et al., 1969). Spilerman (1971) has recently suggested a combination of material inducements with a reward structure emphasizing peer group attainment as a strategy for motivating lower class adolescents. As yet these suggestions have not been tested in large-scale practical programs. However, possible programs along these lines and further research should be encouraged because of the important role that peers play in the educational attainment process.

What does our research tell us about the special problem of equality of opportunity for higher education for women? Our analysis indicates that women make better grades in high school than men. Yet, they are dis- advantaged at every level of higher education. Our data do not bear directly on all of the sources of these disadvantages, but they do suggest that parents are less likely to encourage high educational aspirations among their daughters than their sons, and that whenever family funds are short parents are more likely to spend them on the sons' education. We also know that women have lower educational aspirations than men. This is no doubt in part due to their uncertainty about career and marriage opportunities and plans. But these factors do not fully account for the lower educational attainments of women. We suspect that a narrow sex-role training that stresses household and family roles for women over educational and occupational opportunitiesand which becomes most salient when young women for the first time face the realities of discrimination in higher education and the job market-plays a major part in depressing the women's post-secondary educational attainments.

I endorse the policy recommendations which women have frequently suggested for achieving equality of opportunity for women in higher education, such as requirements that all scholarships, fellowships, part-time jobs, assistantships, and admission to all types of training must be equally open to women and men. Existing rules covering residency, full-time enrollment, and credit transfers should be revised to accommodate the needs of women, and child care centers should be established at all institutions. Also there should be courses in the schools to broaden the conceptions of male and female roles, to reduce prejudice toward women's full participation in all institutional areas, and, particularly, to further encourage women to form (and men to accept) a lifelong commitment to educational and occupational achievement. Educational institutions should also lead the way in equal employment programs. All positions, including top administrative jobs, must be equally open to women and men. Women should receive equal pay for equal rank and be considered for faculty tenure on the same standards as men. Also, educational institutions and other organizations must show greater imagination and flexibility in facilitating part-time professional involvement 
and rewarding careers for women who choose to combine occupational careers with child rearing. Programs to change public attitudes, and particularly those of parents toward female children, doubtless will be necessary, too, if women are not to be discriminated against in higher education and in most other areas of American life.

Finally, special programs will need to be undertaken to increase the participation of blacks, Chicanos, Puerto Ricans, and American Indians in higher education. The measures designed for the poor, if applied without discrimination, would go a long way to reduce the problems of minorities because these minorities are disproportionately represented among low-income families. But we also know that these minorities suffer added disadvantages of discrimination in housing, employment, health care, and in most other areas of American life, and in their personal relations with whites. Discrimination has left many of them not only disadvantaged educationally, but with a well-merited distrust of American institutions and promises of equality in the future. They are likely to distrust educational programs that are planned and carried out by the white majority, and they may also question the relevance of many existing programs of higher education for their personal and community needs. Much joint effort will have to be devoted to revision of existing programs and the establishment of more relevant programs for special needs of minorities. These programs must include ways of making the adjustment to academic life less difficult and should provide opportunities for minority group students to maintain contacts with their communities. Also, much more effort will have to be devoted to recruitment programs designed for the early discovery of potentially talented persons from minority groups and to maximize the development of their abilities and their opportunities. Special efforts must be made to increase the representation of disadvantaged minorities in such professional training programs as law, medicine, and dentistry, and in all graduate training areas. Institutions of higher education must also actively recruit minority staff, faculty, and administrators. And certainly, if increased opportunity for higher education is not to be a sham and a delusion for minor- ity people, it must be accompanied by equal opportunity to participate fully in every aspect of American life.

I would have liked to end this discussion on a note of optimism regarding the immediate prospects for equality of opportunity in higher education. I cannot do so. Our research has shown that the process of higher educational attainment is an exceedingly complex one, and that there are no simple and easy prescriptions for attaining equality of opportunity. Many avenues must be tried, but our knowledge of how to mount successful programs, even in the areas we know are important, is far from perfect. Moreover, political problems abound, and national, state, and local priorities do not currently favor increased expenditures for higher education-and particularly not for novel programs. Many colleges and universities are in severe financial difficulties (Cheit, 1971) and may find it necessary to cut their current inadequate levels of expenditure for opportunity programs of all kinds. In the current emergency many of them are increasing tuition without providing additional scholarship opportunities for needy students. Most experts agree that it will take added annual expenditures running into the billions to provide equality of opportunity for higher education, and that the federal government must provide an increasing proportion of the necessary funds. ${ }^{23}$

On the other hand, pressures are mounting, especially from disadvantaged minorities and from many educators and other citizens. The Carnegie Commission on Higher Education, composed of a number of distinguished citizens and educators, recently announced the following national goals: "That (by 1976) the economic barriers to higher education be removed" and "That (by 2000) all remaining barriers to equality of opportunity which are subject to public policy

\footnotetext{
${ }^{23}$ The Kerr Commission estimates that expenditures for higher education must be increased from 17.2 billions in 1967-68 to 41 billions in 1976-77 if equality of opportunity for higher education is to be broadly extended and quality is to be maintained. This would require an increase in federal expenditures from 3.5 to 13.0 billions. The Commission estimates that this would be less than oneseventh of the projected increase in federal revenues in the next several years (Carnegie Commission on Higher Education, 1968, 1970b).
} 
be removed so that ability, motivation, and choice are the only determinants of college attendance" (Carnegie Commission on Higher Education, 1968, 1970a, 1970b). That these are financially feasible goals is documented in their reports, but the pace of the action must be stepped up considerably if either goal is to be achieved. To date, the Congress and the Administration have fallen far short on legislation and appropriations to equalize educational opportunities.

It is a sociological truism that great gaps often exist between stated goals and their implementation. Americans of all political persuasions have expressed the view that equality of educational opportunity is an essential prerequisite for a well-functioning, democratic society. The programs I have discussed detail some measures necessary to begin to implement this essential need. I urge you as citizens to join me in working for their implementation and as sociologists to join me in pursuing further research which will more clearly specify the most effective alternative programs.

\section{REFERENCES}

Aigner, D. J.

1970 "A comment on problems in making inferences from the Coleman Report." American Sociological Review 35 (March):249252.

Bachman, Jerald G., Robert L. Kahn, Martha T. Mednick, et al.

1969 Youth In Transition, Volume 1. Ann Arbor: Institute for Social Research, The University of Michigan.

Becker, Gary S.

1946 Human Capital. New York: Columbia University Press.

Berg, I.

1970 Education and Jobs: The Great Training Robbery. New York: Praeger.

Blau, Peter M. and Otis Dudley Duncan

1967 The American Occupational Structure. New York: John Wiley.

Bloom, Benjamin S.

1964 Stability and Change in Human Characteristics. New York: John Wiley.

Bowman, Mary Jean

1971 "Economics of education." Pp. 37-70 in Orwig (ed.), Financing Higher Education: Alternatives for the Federal Government. Iowa City: American College Testing Program.

Cain, Glen G. and Harold W. Watts

1970 "Problems in making policy inferences from the Coleman Report." American Sociological Review 35 (April):228-242.
Carnegie Commission on Higher Education

1968 Quality and Equality: New Levels of Federal Responsibility for Higher Education. New York: McGraw-Hill.

1970a A Chance to Learn: An Action Agenda for Equal Opportunity in Higher Education. New York: McGraw-Hill.

1970b Quality and Equality: Revised Recommendations, New Levels of Federal Responsibility for Higher Education. New York: McGraw-Hill.

1971 Less Time, More Options: Education Beyond the High School. New York: McGraw-Hill.

Cheit, Earl F.

1971 The New Depression in Higher Education: A Study of Financial Conditions at 41 Colleges and Universities. New York: McGraw-Hill.

Coleman, J. S.

1965 Adolescents and the Schools. New York: Basic Books.

1968 "The concept of equality of educational opportunity." Harvard Educational Review 38 (Winter):7-22.

1970 "Equality of educational opportunity: Reply to Cain and Watts." American Sociological Review 35 (April):242-249.

Coleman, J. S., Ernest Q. Campbell, Carl F. Hobson, et al.

1966 Equality of Educational Opportunity. Washington: U.S. Office of Education.

Deutsch, Martin and Associates

1967 The Disadvantaged Child. New York: Basic Books.

Duncan, Beverly and Otis Dudley Duncan

1968 "Minorities and the process of stratification." American Sociological Review 33 (June) :356--364.

Duncan, Otis Dudley

1968 "Inheritance of poverty or inheritance of race?" Pp. 85-110 in Daniel P. Moynihan (ed.), On Understanding Poverty. New York: Basic Books.

1969 "Inequality and opportunity." Population Index 35 (October-December):361-366.

Eckland, Bruce

1967 "Genetics and sociology: A reconsideration." American Sociological Review 32 (April): 173-194.

Educational Testing Service

1957 Background Factors Relating to College Plans and College Enrollment Among Public High School Students. Princeton, New Jersey: Educational Testing Service.

Eells, Kenneth, Allison Davis, Robert Havighurst, et al.

1950 Intelligence and Cultural Differences. Chicago: University of Chicago Press.

Effrat, Andrew, Roy Feldman, and Harvey $M$. Sapolsky

1969 "Inducing poor children to learn." The Public Interest 15 (Spring):106-112.

Flanagan, J. C., W. W. Cooley, P. R. Lohnes, et al. 1966 Project Talent One-Year Follow-up Studies. Final report to the U.S. Office of 
Education, Cooperative Research Project No. 2333. Pittsburgh: Project Talent Office, University of Pittsburgh.

Flanagan, J. C., J. T. Dailey, Marion F. Shaycoft, et al.

1962a The Talents of American Youth, Volume 1. Design for a Study of American Youth. Boston: Houghton Mifflin.

1962b Studies of the American High School. Final Report to the U.S. Office of Education, Cooperative Research Project No. 226. Washington: Project Talent Office, University of Pittsburgh.

Flanagan, J. C., F. B. Davis, J. T. Dailey, et al.

1964 The American High-School Student. Final report to the U.S. Office of Education, Cooperative Research Project No. 635. Pittsburgh: Project Talent Office, University of Pittsburgh.

Folger, John K., Helen S. Astin, and Alan Bayer 1970 Human Resources and Higher Education. New York: Russell Sage Foundation.

Gordon, Edmund W.

1971 "Programs and practices for minority group youth in higher education." Pp. 109-126 in Stephen W. Wright (ed.), Barriers to Higher Education. New York: College Entrance Examination Board.

Gordon, Edmund W. and Doxey A. Wilkerson

1966 Compensatory Education for the Disadvantaged. New York: College Entrance Examination Board.

Goslin, David A.

1963 The Search for Ability. New York: Russell Sage Foundation.

Hansen, W. Lee and Burton A. Weisbrod

1969a "The distribution of costs and direct benefits of public higher education: The case of California." Journal of Human Resources 4 (Spring):176-191.

$1969 \mathrm{~b}$ "The search for equality in the provision and finance of higher education." Pp. 107-123 in The Economics and Financing of Higher Education in the United States. Washington: U.S. Government Printing Office.

1969c Benefits, Costs, and Finance of Higher Education. Chicago: Markham.

1971a "On the distribution of costs and benefits of public higher education: Reply." Journal of Human Resources 6 (Summer): 363-374.

1971b "A new approach to higher education finance." Pp. 117-142 in Orwig (ed.), Financing Higher Education: Alternatives for the Federal Government. Iowa City: American College Testing Program.

Hartman, Robert W.

1970 "A comment on Pechman-Hansen-Weisbrod controversy." Journal of Human Resources 5 (Fall):519-523.

Hauser, Robert $\mathrm{M}$.

1970 "Educational stratification in the United States." Sociological Inquiry 40 (Spring): 102-109.
Henmon, V. A. C. and M. J. Nelson

1954 The Henmon-Nelson Test of Mental Ability: Manual for Administration. Chicago: Houghton-Miffin.

Hess, Robert D. and Roberta Meyer Bea: (eds.) 1968 Early Education. Chicago: Aldine.

Innes, J. T., P. B. Jacobson and R. J. Pellegrin

1965 The Economic Returns to Higher Education: A Survey of Findings. Eugene: The Center for Advanced Study of Educational Administration, University of Oregon.

Jensen, Arthur R.

1969 "How much can we boost IQ and school achievement?" Harvard Educational Review 39 (Winter):1-123.

Joint Economic Committee, Congress of the United States

1969 The Economics and Financing of Higher Education in the United States. Washington: U.S. Government Printing Office.

Lavin, David E.

1965 The Prediction of Academic Performance. New York: Russell Sage Foundation.

Lefever, D. Welty

1959 "Review of Henmon-Nelson test of mental ability." Pp. 470-472 in Oscar Krisen Buros (ed.), The Fifth Mental Measurement Year Book. Highland Park, New Jersey: Gryphom Press.

Lenski, Gerhard

1966 Power and Privilege: A Theory of Social Stratification. New York: McGraw-Hill.

Little, J. Kenneth

1958 A Statewide Inquiry into Decisions of Youth About Education Beyond High School. Madison: School of Education, University of Wisconsin.

Mallan, John $\mathbf{P}$.

1971 "Current proposals for federal aid to higher education: Some political implications." Pp. 303-330 in Orwig (ed.), Financing Higher Education: Alternatives for the Federal Government. Iowa City: American College Testing Program.

Masters, Stanley $\mathrm{H}$.

1969 "The effects of family income on children's education: Some findings on inequality of opportunity." Journal of Human Resources 4 (Spring): 158-175.

Miller, S. M. and F. Reissman

1969 "The credentials trap." Pp. 69-78 in S. M. Miller and F. Reissman (eds.), Social Class and Social Policy. New York: Basic Books.

Miller, S. M. and Pamela Roby

1970 The Future of Inequality. New York: Basic Books.

Morgan, James N. and Martin H. David

1963 "Education and Income." Quarterly Journal of Economics (August):423-437.

Nam, Charles B. and James D. Cowhig

1962 "Factors related to college attendance of farm and nonfarm high school graduates: 1960." U.S. Department of Commerce, U.S. Depariment of Agriculture, Farm Population, Series Census-ERS (P-27) 32 
(June). Washington: U.S. Government Printing Office.

Newman, Frank (ed.)

1971 Report on Higher Education. Washington: U.S. Government Printing Office.

Organization for Economic Cooperation and Development

1971 Equal Educational Opportunity. Paris: OECD, Center for Educational Research and Innovation.

Orwig, M. D. (ed.)

1971a Financing Higher Education: Alternatives for the Federal Government. Iowa City: American College Testing Program.

$1971 \mathrm{~b}$ "The federal government and the finance of higher education." Pp. 331-360 in Orwig (ed.), Financing Higher Education: Alternatives for the Federal Government. Iowa City: American College Testing Program.

Parnes, Herbert S., Robert C. Miljus, Ruth S. Spitz and Associates

1970 Career Thresholds: A Longitudinal Study of the Educational and Labor Market Experience of Male Youth, Volume 1. Washington: U.S. Department of Labor, Manpower Administration.

Pechman, Joseph A.

1970 "The distributional effects of public higher education in California." Journal of Human Resources 5 (Summer):361-370.

1971 "The distribution of costs and benefits of public higher education." Journal of $\mathrm{Hu}$ man Resources 6 (Summer):375-376.

Rainwater, Lee

1970 Behind Ghetto Walls: Black Family Life in a Federal Slum. Chicago: Aldine.

Rivlin, Alice M.

1970 "Equality of Opportunity and Public Policy." Pp. 6-11 in College Entrance Examination Board, Financing Equal Opportunity in Higher Education. New York: College Entrance Examination Board.

Schultz, Theodore W.

1963 The Economic Value of Education. New York: Columbia University Press.

Sewell, William H.

1964 "Community of residence and college plans." American Sociological Review 29 (February) :24-38

Sewell, William H. and J. Michael Armer

1966a "Neighborhood context and college plans." American Sociological Review 31 (April): 159-168.

1966b "Response to Turner, Michael and Boyle." American Sociological Review 31 (October) :707-712.

Sewell, William H. and Archibald O. Haller

1965 "Educational and occupational perspectives of farm and rural youth." Pp. 149169 in Lee G. Burchinal (ed.), Rural Youth in Crisis: Facts, Myths, and Social Change. Washington: U.S. Government Printing Office.

Sewell, William H., Archibald O. Haller, and George W. Ohlendorf

1970 "The educational and early' occupational status achievement process: Replication and revision." American Sociological Revicw 35 (December):1014-1027.

Sewell, William H., Archibald O. Haller, and Alejandro Portes

1969 "The educational and early occupational attainment process." American Sociological Review 34 (February):82-92.

Sewell, William H., Robert M. Hauser, and Vimal P. Shah

n.d. Social Status and Higher Education. Unpublished.

Sewell, William H. and Vimal P. Shah

1967 "Socioeconomic status, intelligence, and the attainment of higher education." Sociology of Education 40 (Winter):1-23.

1968 a "Social class, parental encouragement, and educational aspirations." American Journal of Sociology 73 (March):559-572.

1968b "Parents' education and children's educational aspirations and achievements." American Sociological Review 33 (April): 191-209.

Shaycoft, Marion F.

1967 The High School Years: Growth in Cognitive Skills. Interim Report 3 to the U.S. Office of Education, Cooperative Research Project No. 3051. Pittsburgh: Project Talent Office, American Institutes for Research and University of Pittsburgh.

Shaycoft, Marion F., J. T. Dailey, D. B. Orr, et al.

1963 Studies of a Complete Age Group-Age 15. Final report to the U.S. Office of Education, Cooperative Research Project No. 635. Pittsburgh: Project Talent Office, University of Pittsburgh.

Sorokin, Pitirim

1927 Social Mobility. New York: Harper \& Brothers.

Spady, William G.

1967 "Educational mobility and access: Growth and paradoxes." American Journal of Sociology 73 (November):273-279.

Spilerman, Seymour

1971 "Raising academic motivation in lower class adolescents: A convergence of two research traditions." Sociology of Education 44 (Winter) : 103-118.

Trent, James W. and Leland L. Medsker

1968 Beyond High School. San Francisco: Jossey-Bass.

U.S. Bureau of the Census

1960 Census of Population 1960, Volume 1. Characteristics of the Population, Part I, U.S. Summary, Table 173 and Current Population Reports, Population Characteristics, Series P-20, No. 207, Table 1. Washington: U.S. Governnent Printing Office.

1961 "School enrollment, and education of young adults and their fathers: October 1960." Current Population Reports, P-20, 110 (July). Washington: U.S. Government Printing Office.

1969 "Factors related to high school graduation and college attendance: 1967." Current 
Population Reports, Series P-20, 185 (July). Washington: U.S. Government Printing Office.

1970 "Educational Attainment: March 1970." Current Population Reports, Series P-20, 207 (November). Washington: U.S. Government Printing Office.

1971 "School Enrollment: October 1970." Current Population Reports, Series P-20, 222 (June). Washington: U.S. Government Printing Office.

U.S. Department of Health, Education, and Welfare, Office of Assistant Secretary for Planning and Education

1969 Toward a Long Range Plan for Federal Support for Higher Education (A Report to the Presicient). Washington: U.S. Government Printing Office.

Wegner, EIdon and William H. Sewell

1970 "Selection and context as factors affecting the probability of graduation from college." American Journal of Sociology 75 (January):665-679.

Weisbrod, Burton A. and Peter Karpoff

1968 "Monetary returns to college education, student ability, and college quality." Re. view of Economics and Statistics (November):491-497.

Williams, Walter and John W. Evans

1969 "The political evaluation: The case of Head Start." The Annals 385 (September): 118-132.

Willingham, Warren (ed.)

1970 Free Access Higher Education. New York: College Entrance Examination Board.

Wright, Stephen J.

1970 "The financing of equal opportunity in higher education: The problem and the urgency." Pp. 1-5 in College Entrance Examination Board, Financing Equality of Educational Opportunity in Higher Education. New York: College Entrance Examination Board.

Zeller, Frederick A., John R. Shea, Andrew I. Kohen, Jack A. Meyer

1970 Career Thresholds: A Longitudinal Study of the Educational and Labor Market Experience of Male Youth, Volume 2. Columbus, Ohio: The Ohio State University Center for Human Resource Research. Washington: U.S. Department of Labor, Manpower Administration.

\section{MANUSCRIPTS FOR THE ASA ROSE SOCIOLOGY SERIES}

Fellows and Active and Student members of the Association may submit manuscripts of 100 to 300 typed pages for publication in the ASA Arnold and Caroline Rose Monograph Series in Sociology to the Series Editor, Sheldon Stryker, Department of Sociology, Indiana University, Bloomington, Indiana 47401. 